\title{
TRENDS IN OCCUPATIONAL INJURIES - AN OCCUPATIONAL SAFETY INDICATOR IN FORESTRY SECTOR OF BOSNIA AND HERZEGOVINA
}

\author{
UDC 331.45:630(497.6)
}

\section{Biljana Vranješ́ ${ }^{1}$, Mile Vajkić ${ }^{2}$ Lutvo Haznadarević ${ }^{3}$, Marko Đapan ${ }^{4}$, Evica Stojiljković5}

\author{
${ }^{1}$ University of Banja Luka, Faculty of Mechanical Engineering, Banja Luka, \\ Republic of Srpska - Bosnia and Herzegovina, \\ ${ }^{2}$ School of Mechanical Engineering Prijedor, \\ Republic of Srpska - Bosnia and Herzegovina, \\ ${ }^{3}$ College „Logos Centar“ Mostar, Mostar, Bosnia and Herzegovina, \\ ${ }^{4}$ University of Kragujevac, Faculty of Engineering, Kragujevac, Serbia \\ ${ }^{5}$ University of Niš, Faculty of Occupational Safety, Niš, Serbia
}

\begin{abstract}
Occupational safety is the prevention and elimination of dangers and hazards that can cause workplace injuries, occupational and other diseases and damage to the employees' health. According to the modern concept, it implies constant monitoring of the situation with the aim to explore ways and design measures for the improvement of an occupational health and safety system. An effective way to monitor the situation in an occupational health and safety system is to define performance or success indicators, whereas, in practice, the most commonly used tool is occupational safety indicators. Indicators of work-related injuries can be absolute and relative. Since absolute indicators do not provide a realistic image of the state of workplace safety, we shall use relative indicators. A relative indicator of occupational safety often used is the injury frequency index. This indicator was obtained as the ratio of the number of injuries and effective working hours over the observation period or the number of employees in the production and business system. Also, the same indicator can be calculated in relation to the volume of production.

In the forestry sector, where occupational injuries are frequent and often fatal, monitoring indicators of occupational injuries allows us to see the movement of the observed phenomenon (occupational safety) in a certain period, and also to determine the general trend of its movement (decline or growth) and most importantly to develop preventive measures. In addition, the analysis of workplace injuries using the indicators enables the comparison of occupational safety in business systems from the same activity and, thus, foster the transfer of know-how and good practice from the systems with high levels of occupational safety.
\end{abstract}

Received September 26, 2020 / Accepted October 23, 2020

Corresponding author: Biljana Vranješ

Faculty of Mechanical Engineering, Stepe Stepanovića 71, Banja Luka, Republic of Srpska-B\&H,

E-mail: biljana.vranjes@mf.unibl.org 
Key words: occupational safety, occupational injury, frequency index of occupational injury, forestry sector.

\section{INTRODUCTION}

Forest resources management includes cultivation and protection of forests, their exploitation, preservation of forest flora and fauna, but also care for employees through the implementation of adequate occupational safety measures, even though forestry is listed as the second most dangerous industry in the world [1]. Forestry workers are exposed to numerous hazards and harms. The most predominant hazards are mechanical hazards related to the use of work equipment and workplace characteristics, while harms include intense physical effort, physical and chemical hazards related to outdoor work in combination with biological hazards. Occupational safety, which embodies the set of measures, procedures and jobs aimed at providing a safe working environment and favourable working and living conditions for all employees, has found its place in the forest industry.

In the contemporary business world, rapid changes in the environment and the production systems cause changes in processes and, therefore, the changes in the organization and functioning of the occupational safety system. Production systems in the forest industry have certain characteristics and they differ from each other both in terms of organization of labour and workplace safety. An effective way to respond to these challenges is to apply performance indicators in managing occupational safety and health system. These are numerical indicators that provide the company management with information about what happened in the previous period and what the current problems and difficulties in ensuring occupational health and safety are [2,3]. These indicators are tools for measuring and monitoring progress and success in achieving safety goals and managing the results of companies in the field of occupational safety. They are also an instrument of good professional practice in implementing occupational safety strategies. When it comes to the success of the safety system in the company, the dominant purpose of occupational safety indicators is prevention [2]. Occupational safety indicators provide competitive information on the company "state" regarding occupational safety. The need for constant monitoring of the state of the working and living environment and the application of measures that modify the existing situation and reduce the risk requires the application of a systematic approach and the selection of occupational safety performance indicators [3].

One of the most favourable ways to perceive working conditions in a company is the dynamics of accidents that occurred in the analyzed period. The number of occupational injuries in a company indicates the importance and magnitude of problems related to occupational safety and health [4]. Also, the number of workplace injuries, occupational diseases, work-related illnesses, health impairments, and other parameters of occupational trauma (absenteeism, disability, reduced working capacity, etc.) are the basic indicator of working environment conditions and the efficiency of the safety system.

Occupational safety is a change in human integrity (physical, mental and social) that occurred in the work environment, as a consequence of sudden and immediate discrepancies between human behaviour during work and elements of the work environment [5]. The indicator of injuries most often used to show the state of occupational health and safety is the frequency index (coefficient) of occupational injuries. Additional information on the state of occupational safety is obtained by monitoring the trends of indicators over a specific period. 
Therefore, the purpose of this paper is to calculate the occupational injury indices on the example of the forestry sector in Republika Srpska - Bosnia and Herzegovina (RS-B\&H), over the nine years (2011-2019), with the aim of monitoring the state of occupational safety in this industrial activity.

\section{INDICATORS FOR OCCUPATIONAL INJURIES IN THE FOREST INDUSTRY}

Negative consequences of unfavorable working conditions in the work environment can be monitored through absolute and relative indicators of occupational injuries. Figure 1 shows the trends in absolute indicators of serious and fatal injuries in the forestry sector of RS-B\&H over the nine years (2011-2019).

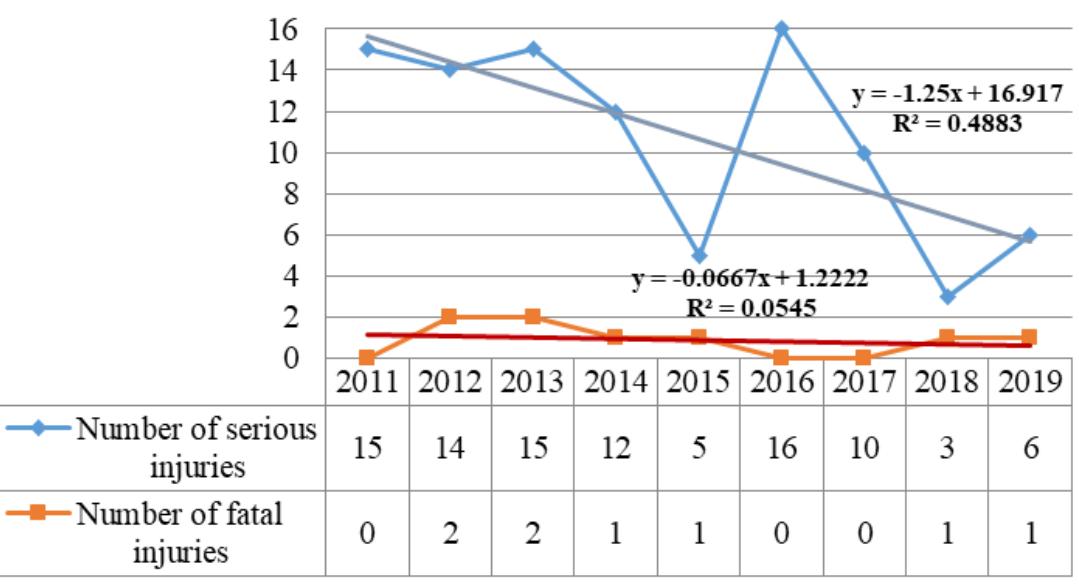

Fig. 1 Trend in serious injury rates and fatal occupational injuries over the 2011-2019 period.

According to the absolute indicators of serious injuries and fatalities shown in Figure 1, it can be seen that there are declining trends in the forestry sector of RS-B\&H, which is rather satisfactory in terms of employee safety. The number of serious injuries in the analyzed period decreased at an annual rate of $11.72 \%$, whereas the annual rate of fatalities was $7.5 \%$. Absolute and relative indicators of occupational injuries and the average number of employees in the forestry sector of RS - B\&H over the nine years (2011-2019) are shown in Table 1. For the observed phenomenon (number of work-related injuries) at different periods, both base and chain indices can be used. Base indices show the rate of occupational injuries in relation to the selected base value (in our case the rate of injuries in the first year of observation), while chain indices refer to the previous year [6,7]. 
Table 1 The rate of occupational injuries and the average number of employees for the 2011-2019 period.

\begin{tabular}{|c|c|c|c|c|}
\hline \multirow{3}{*}{ Year } & \multicolumn{4}{|c|}{ The rate of injuries in the forest industry in RS - B\&H } \\
\hline & \multicolumn{2}{|c|}{ "Forests of Republika Srpska-B\&H" * } & \multicolumn{2}{|c|}{ Index } \\
\hline & Number of injuries ${ }^{\dagger}$ & Number of employees & Base & Chain \\
\hline 2011 & 133 & 4196 & 100.00 & - \\
\hline 2012 & 151 & 4361 & 113.53 & 113.53 \\
\hline 2013 & 160 & 4356 & 120.30 & 106.67 \\
\hline 2014 & 145 & 4515 & 109.02 & 90.62 \\
\hline 2015 & 168 & 4534 & 126.32 & 115.86 \\
\hline 2016 & 152 & 4764 & 114.29 & 90.48 \\
\hline 2017 & 171 & 4847 & 128.57 & 112.50 \\
\hline 2018 & 137 & 4969 & 103.01 & 80.59 \\
\hline \multirow[t]{3}{*}{2019} & 152 & 4887 & 114.29 & 110.95 \\
\hline & Total & 1369 & 41429 & \\
\hline & Annual average & 152 & 4603 & \\
\hline
\end{tabular}

From the above data, we see that since 2011, there has been an increase in the annual number of injuries in the forestry sector of RS - B\&H, whereas in 2017 there was the highest number of injuries in the observed period (171 injuries), with an increase of $28 \%$ compared to the base value; finally, in 2019 there was an increase of $14 \%$ compared to the initial year.

For a more complete overview of the state of occupational health and safety in forestry, in this paper, we used the indicators of injuries depending on the number of employees, the number of effective working hours, among which is the index (coefficient) of the frequency of injuries.

This index can be calculated in relation to the volume of production, i.e. the volume of the wood log over the observed period. Due to the need to determine the general movement (decline or growth) of the state of occupational safety, it is convenient to use the method of dynamic linear model (DLM) trend, with the aim to take additional measures of workplace safety.

The frequency index of occupational injuries per number of employees $\left(F I_{e}\right)$ is calculated using the expression $[7,8,9]$ :

$$
F I_{e}=\frac{O I}{E} \cdot 10^{3}
$$

where:

$O I$ - the rate of occupational injuries

$E$ - the number of employees.

Figure 2 shows the values and trends in the frequency index of occupational injuries per number of employees in the forestry sector in RS - B\&H over the period 2011-2019 period.

\footnotetext{
* Public forest company "Forests of Republika Srpska - B\&H" joint-stock company Sokolac

${ }^{\dagger}$ Total number of injuries in forest industry in RS - B\&H
} 
Trends in Occupational Injuries - an Occupational Safety Indicator in Forestry Sector of Bosnia and Herzegovina 189

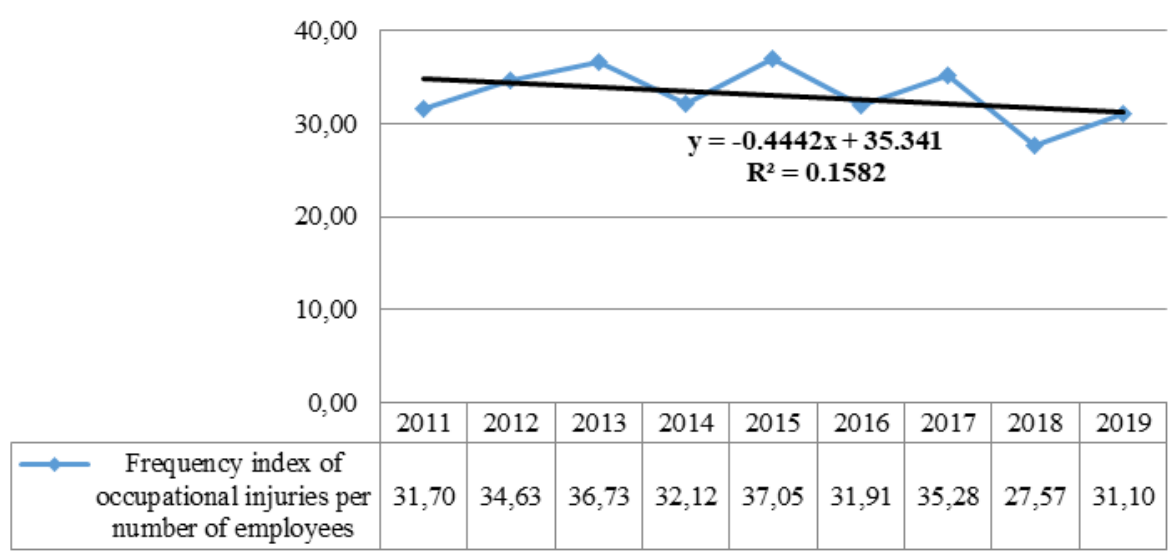

Fig. 2 Trends in the frequency index of occupational injuries per number of employees over the 2011-2019 period.

Based on the above values, we can conclude that there is a slight declining trend in the frequency index of occupational injuries per number of employees in the forestry sector in RS $-\mathrm{B} \& \mathrm{H}$, with an annual rate of decline of $1.34 \%$. However, the average value for the research period which amounted to $33.12 \%$ is higher than the European average of $28.12 \%$ for 2017 . According to the trend in the frequency index of occupational injuries per number of employees, its value should be around 30 . The frequency index of occupational injuries per effective working hours $\left(F I_{e w h}\right)[7,9]$ :

$$
F I_{e w h}=\frac{O I}{H} \cdot 10^{6}
$$

where:

$O I$ - the rate of occupational injuries

$H=E \cdot w_{h}$ - the number of effective working hours $(H)$ in the observed period (year) is the product of the number of employees $(E)$ and working hours $\left(w_{h}\right)$.

For calculation of the injury frequency index it was rather it was not possible to provide records on the exact effective working hours; therefore, the approximate number of working hours for the analyzed period was calculated. In order to obtain average annual working hours, we shall use the following formula: $40 \mathrm{~h}$ per week $\cdot 52$ working weeks $=$ $2080 h$. From this value, we deduce the average number of working hours during the year when employees are absent from work, in the following manner: $2020 h-375 h=1712 h$. These hours usually involve 20 days of annual leave, 8 days of paid public holidays, 14 days of sick leave and 5 days of absence due to other reasons. The approximate number of effective working hours can be obtained by multiplying the number of employees by 1712 hours. The suggestion for future research is to provide data on the real number of effective working hours in the forestry sector of RS - B\&H in order to obtain accurate values for this indicator. Figure 3 shows the values and trends in injury frequency index per approximate effective working hours in the forestry sector of RS - B\&H over the 2011-2019 period. 


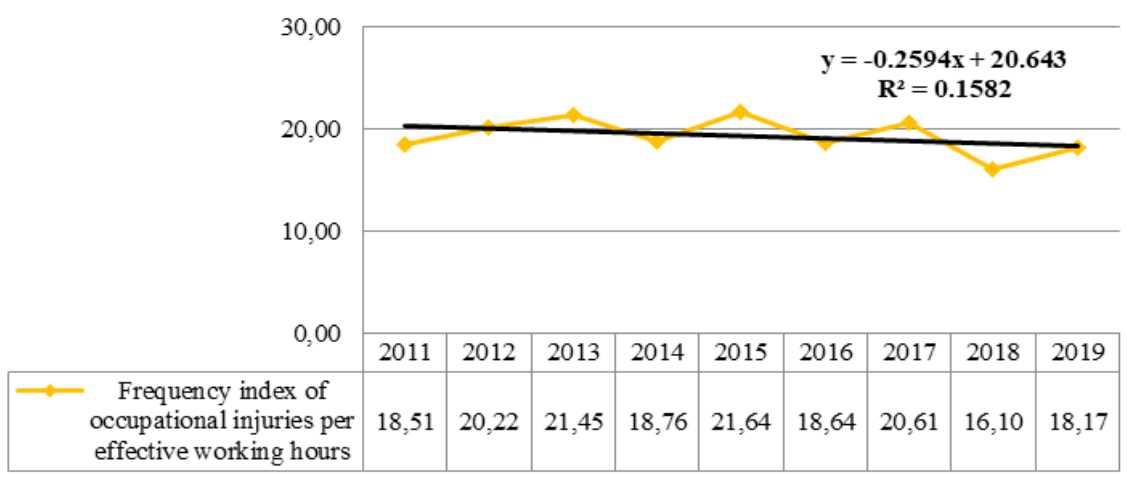

Fig. 3 Trends in the frequency index of occupational injuries per effective working hours over the 2011-2019 period.

The injury frequency index in relation to the wood log volume $\left(F I_{v}\right)$ is calculated using the expression:

$$
F I_{v}=\frac{O I}{V_{w l}} \cdot 10^{6}
$$

where:

$O I$ - the rate of occupational injuries

$V_{w l}-$ wood $\log$ volume $\left(\mathrm{m}^{3}\right)$.

Based on the available data, Figure 4 shows the trend in occupational injuries in relation to the wood log volume in the forest industry of RS - B\&H for the 2011-2017 period.

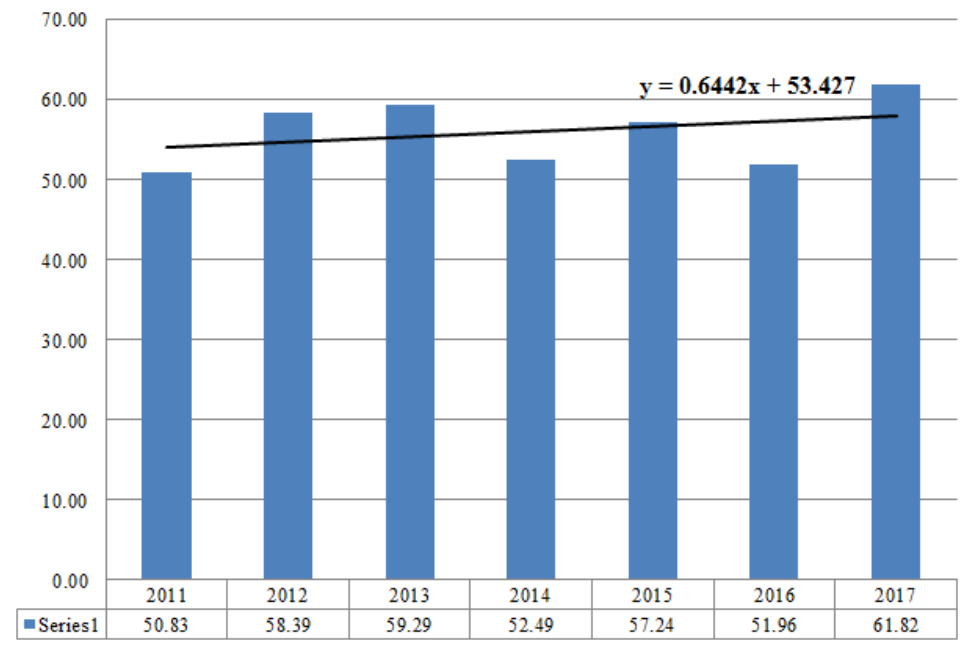

Fig. 4 Trend in injury frequency index in relation to the wood log volume for the 20112017 period.

Based on the data in the previous figure, we can conclude that there is a slight growing trend of injury frequency index in relation to the wood log volume in the forestry sector of RS 
$-\mathrm{B} \& \mathrm{H}$, with an annual growth rate of $1.15 \%$. In order to obtain a clear image of what the situation in high-risk activities, such as forestry, really is, we should take into account the fatal accident frequency index $\left(F I_{f a}\right)[7,9]$ :

$$
F I_{f a}=\frac{O I_{f a}}{E} \cdot 10^{4}
$$

where:

$O I_{f a}$ - number of fatal occupational injuries

$E$ - number of employees

Figure 5 depicts the values and trends in the fatal accident frequency index in the forestry sector in RS - B\&H for the 2011-2019 period.

Bearing in mind the above-mentioned values, we can conclude that there is a declining trend in the frequency index of fatal occupational injuries in the forestry sector of RS $\mathrm{B} \& \mathrm{H}$, with an annual rate of decline of $9.29 \%$. According to that model, there is a high probability of one fatal injury per year in the following period.

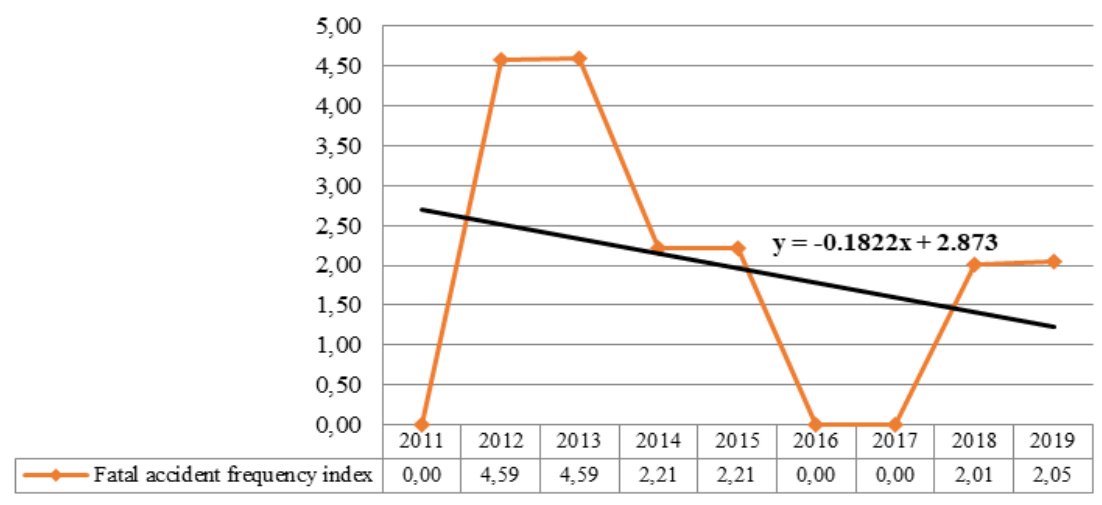

Fig. 5 Trend in fatal accident frequency index for the 2011-2019 period.

An average value of injury frequency index in relation to the wood log volume is $0.31 \mathrm{~m}^{3}$ (2011-2017), which displays an extremely good state of occupational safety when compared to other European countries [10]. One of the advantages of occupational safety assessment using the injury frequency index is the comparability of indices within companies in different periods or within companies from the same industry, which involve jobs with similar risks.

\section{CONCLUSION}

A modern approach to occupational safety system management, within a certain industry such as forestry, is a simple and efficient model used to review and analyze the current state of occupational safety in the production system, with the possibility of predicting the outcome by monitoring the trend of various indicators. The application of this model is based on defining, measuring, monitoring and reviewing performance indicators. Despite the declining trends in occupational safety injuries in the forestry sector, except for the indicators which refer to production volume (yet in accordance with European standards), there is a need to 
optimize the existing system of occupational safety. In addition, this is supported by the fact that performance indicators are beyond the tolerance limits when it comes to the number of employees, bearing in mind the requirements for additional preventive measures.

\section{REFERENCES}

1. Garland, J. J., (2018), Accident reporting and analysis in forestry: guidance on increasing the safety of forest work. In: Proceedings of the Forest Engineering Conference, vol. 17, Rotorua, New Zealand.

2. Vranješ, B., Todić, M., (2019), A model of analysis of the occupational safety and health system in the production system, Journal of Applied Engineering Science, No. 3, pp. 264-272, doi: 10.5937/jaes17-21372.

3. Petras, M., Begović, I., Palačić, D., (2014), Ključni pokazatelji uspješnosti procesa zaštite zdravlja i sigurnosti na radu i zaštite okoliša, Praktični menadžment, Vol. V, Br. 1, str. 68-78 (in Croatian).

4. Stojiljković, E., Krstić, I., Jovanović, M. (2011). Analiza povreda na radu u Ogranku ED Leskovac u funkciji upravljanja rizikom. Zbornik radova sa nacionalne konferencije sa međunarodnim učešćem: Zaštita na radu u 21. veku - teorija i praksa. (04-08.10.2011). Novi Sad: Univerzitet u Novom Sadu, Fakultet tehničkih nauka, Departman za inženjerstvo zaštite životne sredine i zaštite na radu, str. 173-178 (in Serbian).

5. Krstić, I., Anđelković, B., (2013), Profesionalni rizik, Niš: Univerzitet u Nišu, Fakultet zaštite na radu u Nišu (in Serbian).

6. Vranješ, B., Vajkić, M., Tanasić, Z., (2019), Injury indicators trend in the quality control of occupational safety and health, International Journal Occupational Safety and Health, Engineering Management \& Applied Engineering, Volume 1, Issue 1, pp. 5-11.

7. Spasić, D., (2001), Ekonomika zaštite na radu, Niš: Grafičko preduzeće SVEN (in Serbian).

8. Krstić, I., (2010), Modeli za sistemsku analizu rizika tehnoloških sistema, Doktorska disertacija, Niš: Univerzitet u Nišu, Fakultet zaštite na radu u Nišu (in Serbian).

9. Anđelković, B., (2002), Rizik tehnoloških sistema i profesionalni rizik, Monografija, Niš: Jugoslovenski savez Društva inženjera i tehničara zaštite (in Serbian).

10. Albizu-Urionabarrenetxea, P. M., Tolosana-Esteban, E., Roman-Jordan, E., (2013), Safety and health in forest harvesting operations. Diagnosis and preventive actions. A review Forest Systems, Vol. 22, No. 3, pp. 392-400.

\section{TREND POVREDA NA RADU - INDIKATOR STANJA ZAŠTITE NA RADU U ŠUMARSTVU BOSNE I HERCEGOVINE}

Zaštita na radu podrazumjeva sprečavanje $i$ otklanjanje opasnosti $i$ štetnosti koje mogu prouzrokovati povrede na radu, profesionalne i druge bolesti $i$ oštećenja zdravlja radnika. Prema savremenom konceptu ona obuhvata stalno praćenje indikatora zaštite na radu s ciljem otkrivanja načina i projektovanja mjera za unapređenje sistema bezbjednosti (zaštite) $i$ zdravlja na radu. Efikasan način za praćenje stanja u sistemu bezbjednosti i zdravlja na radu je definisanje pokazatelja uspješnosti ili performansi, a najčešće korišćeni u praksi su pokazatelji povreda na radu. Pokazatelji povreda na radu mogu biti apsolutni i relativni. Budući da apsolutni pokazatelji ne daju realnu sliku stanja zaštite na radu koriste se relativni pokazatelji. Relativni pokazatelj povreda na radu koji se često koristi je indeks učestalosti povreda na radu. Ovaj pokazatelj se dobija kao odnos broja povreda na radu i ostvarenih efektivnih sati rada svih radnika u posmatranom periodu ili broja zaposlenih u proizvodno-poslovnom sistemu. Takođe, isti pokazatelj se može izrčunavati i u odnosu na obim proizvodnje.

$U$ šumarstvu, gđe su povrede na radu česte i nerijetko sa smrtnim ishodom, praćenje pokazatelja povreda na radu omogućava sagledavanje kretanja posmatrane pojave (zaštite na radu) u određenom vremenskom periodu, utvrđivanje opšte tendencije njenog kretanja (opadanje ili rast) $i$ najvažnije projektovanje preventivnih mjera za korekciju stanja. Takođe, analiza povreda na radu primjenom pokazatelja omogućava upoređivanje stanja zaštite na radu u poslovnim sistemima iz iste delatnosti i na taj način razmjenu iskustava dobre prakse sa onim sistemima gde je stanje zaštite na radu na višem nivou.

Ključne reči: zaštita na radu, povreda na radu, indeks učestalosti povreda na radu, šumarstvo. 